\title{
RESEARCH
}

Open Access

\section{Mortality due to primary brain tumours in China and detection rate in people with suspected symptoms: a nationally representative cross-sectional survey}

Bin Jiang ${ }^{1,2^{*}}$ (D) Hongmei Liu ${ }^{1,2,3}$, Dongling Sun ${ }^{1,2}$, Haixin Sun ${ }^{1,2}$, Xiaojuan $\mathrm{Ru}^{1,2}$, Jie Fu ${ }^{1,2}$, Siqi Ge $\mathrm{e}^{1,2}$ and Wenzhi Wang ${ }^{1,2,3}$

\begin{abstract}
Background and purpose: Epidemiological data on primary brain tumours (PBTs) are lacking due to the difficulty in case ascertainment among the population. Thus, we aimed to estimate mortality due to PBTs in China nationwide and the detection rate in people with suspected symptoms.

Methods: A multistage, complex sampling survey regarding mortality due to PBTs in Chinese individuals was carried out by reviewing all causes of death within a year. The detection rates in people with suspected symptoms were estimated based on PBT symptom screening and neurologist reviews and compared between groups by logistic regression analysis.

Results: Weighted mortality due to PBT was 1.6 (0.8-3.3) per 100,000 population in Chinese individuals, 1.8 (0.7-4.6) per 100,000 population in men, and $1.5(0.5-4.5)$ per 100,000 population in women. Among 14,990 people with suspected symptoms, the PBT detection rate was 306.9 (95\% Cl 224.7-409.3) per 100,000 population in the total population, 233.0 (95\% Cl 135.7-373.1) per 100,000 population in men, and 376.9 (95\% Cl 252.4-546.3) per 100,000 population in women. People with an unsteady gait (OR 2.46; $95 \% \mathrm{Cl} 1.09-5.51 ; P=0.029)$, visual anomalies (3.84; $1.88-7.85 ; P<0.001)$, and headache $(2.06 ; 1.10-3.86 ; P=0.023)$ were more likely to have a brain tumour than those without corresponding symptoms, while people with dizziness/vertigo were less likely to have a brain tumour than those without corresponding symptoms $(0.45 ; 0.23-0.87 ; P=0.017)$.

Conclusions: Mortality due to PBT in China was low, with a nationwide estimate of 21,215 $(10,427-43,165)$ deaths attributable to PBTs annually. However, the detection rate of PBTs can be greatly improved based on symptom screening in the population.
\end{abstract}

Keywords: Epidemiology, Mortality, Detection rate, Primary brain tumours, China

\footnotetext{
* Correspondence: bjyjiang@hotmail.com; bjyjiang@163.com

'Department of Neuroepidemiology, Beijing Neurosurgical Institute, Beijing

Tiantan Hospital, Capital Medical University, No. 119, South Fourth Ring Road

West, Fengtai District, Beijing 100070, People's Republic of China

${ }^{2}$ Beijing Municipal Key Laboratory of Clinical Epidemiology, Beijing, People's

Republic of China

Full list of author information is available at the end of the article
}

C C The Author(s). 2021 Open Access This article is licensed under a Creative Commons Attribution 4.0 International License, which permits use, sharing, adaptation, distribution and reproduction in any medium or format, as long as you give appropriate credit to the original author(s) and the source, provide a link to the Creative Commons licence, and indicate if changes were made. The images or other third party material in this article are included in the article's Creative Commons licence, unless indicated otherwise in a credit line to the material. If material is not included in the article's Creative Commons licence and your intended use is not permitted by statutory regulation or exceeds the permitted use, you will need to obtain permission directly from the copyright holder. To view a copy of this licence, visit http://creativecommons.org/licenses/by/4.0/. The Creative Commons Public Domain Dedication waiver (http://creativecommons.org/publicdomain/zero/1.0/) applies to the data made available in this article, unless otherwise stated in a credit line to the data. 


\section{Introduction}

Primary brain tumours (PBTs) are characterized by high rates of case fatality and disability [1]. However, epidemiological data on PBTs are lacking due to difficulty in brain tumour case ascertainment among people without specific symptoms in the population. In the USA [2, $3]$ and Europe [4], the prevalence of primary brain tumour in the population can be estimated from brain tumour-related incidence and survival data. There are three major symptoms of brain tumour: headache, vomiting, and blurred visions due to optic disc oedema, and motor and sensory dysfunctions. Although these symptoms are nonspecific, it seems to be feasible to investigate individuals' symptoms in the population. Thus, we adopted a multistage, complex sampling method to investigate mortality due to PBTs in China and the detection rate in people with suspected symptoms (/signs) by innovatively establishing a two-step method, including screening for common central nervous system symptoms that overlap with stroke by staff from China's Center for Disease Control and Prevention and differentiating brain tumour and stroke cases by neurologists based on the national epidemiological survey of cerebrovascular diseases in China [5-9].

\section{Methods}

\section{Sampling and participants}

The complex, multistage probability sampling design used to define the sampling frame and the participants has been described in detail in previous studies [5-7]. In brief, 2010 Chinese population census data and probability proportionate to population size (PPS) sampling were used to select 64 urban and 93 rural areas from 31 provinces of China [i.e., 157 disease surveillance points (DSPs) or survey sites shown in Fig. 1]. In the first stage of sampling, PPS sampling was again used to select 'neighbourhoods' (Jiedao) within cities or 'townships' (Xiang) in rural areas; the probability of selection was based on the population size of the neighbourhood or township. In the second stage of sampling, one or more neighbourhood committees (administrative villages) with a total population of at least 4500 residents (approximately 1500 households) were selected from the sampled neighbourhoods (townships) at each site using random cluster sampling. The participants included people who had lived in the county (or district) for at least 6 months in the past year. Trained investigators visited these participants at least 3 times on different dates. For this survey, 602,715 people in 155 DSPs were evaluated, with a response rate of $80.8 \%$ among 745,588 people [6].

\section{Case ascertainment and quality assurance}

The national survey on brain tumours and stroke was conducted with face-to-face household interviews. From September 1, 2013, through December 31, 2013, CDC investigators visited each household, collected participants' signed informed consent forms and completed the preliminary screening form. This questionnaire included basic information about family members, symptoms, and the medical history of the individual. In this

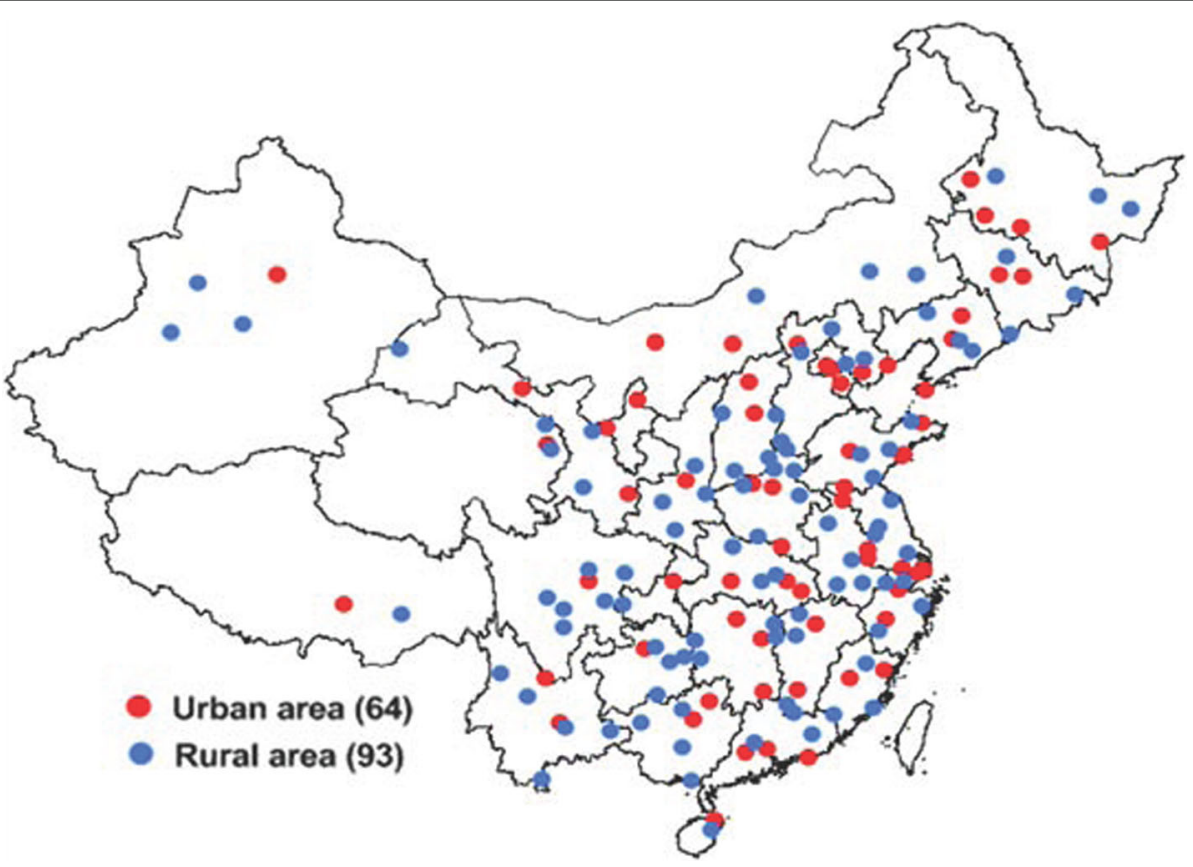

Fig. 1 Distribution of survey sites in 31 provinces of China 
survey, participants with at least one of eight symptoms $(n=26595)$ including sudden unconsciousness $(n=7952)$; weakness in the face, arms, or legs on one side of the body ( $n=7823)$; numbness in the face, arms, or legs on one side of the body $(n=11261)$; blurred vision $(n=$ 10757); difficulty speaking $(n=5617)$; difficulty understanding $(n=3789)$; dizziness or gait instability $(n=$ 16033); or severe headache with or without nausea/ vomiting $(n=13906)$ were identified by China's Center for Disease Control and Prevention (CDC) investigators and subsequently interviewed by neurologists. After preliminary screening, participants with symptoms or history suggestive of brain tumour were invited to see a neurologist in a town/village clinic. Their medical records [e.g., disease history, head computed tomography (CT) and magnetic resonance imaging (MRI) scans] were carefully reviewed, and relevant data were recorded. At the review/confirmation stage of the survey, neurologists interviewed 26,305 participants with one of the abovementioned eight symptoms and completed relevant case adjudication forms. Neurological examinations and reviews were completed for $98.9 \%$ of the eligible patients. Among these study participants, 14, 990 suspected cases had CT/MRI or histopathological confirmation (Fig. 2). The validated verbal autopsy technique involving household members of people who died within the 12 months preceding the survey was used to identify PBT as a possible cause of death. Ultimately, 46 surviving patients and 15 decedents were diagnosed with PBT by neurologists (Fig. 2).

Detailed quality assurance methods have been described in previous studies [5-7]. In brief, quality control was performed in all phases of the survey, and survey preparations, field work, and data processing were all supervised.

\section{Diagnostic criteria}

PBTs were defined as tumours originating from the brain, brain stem, meninges, cranial nerves, and other parts of the brain or the intracranial endocrine glands. Tumours involving only the spinal cord were not included. The diagnostic criteria for PBT in this study

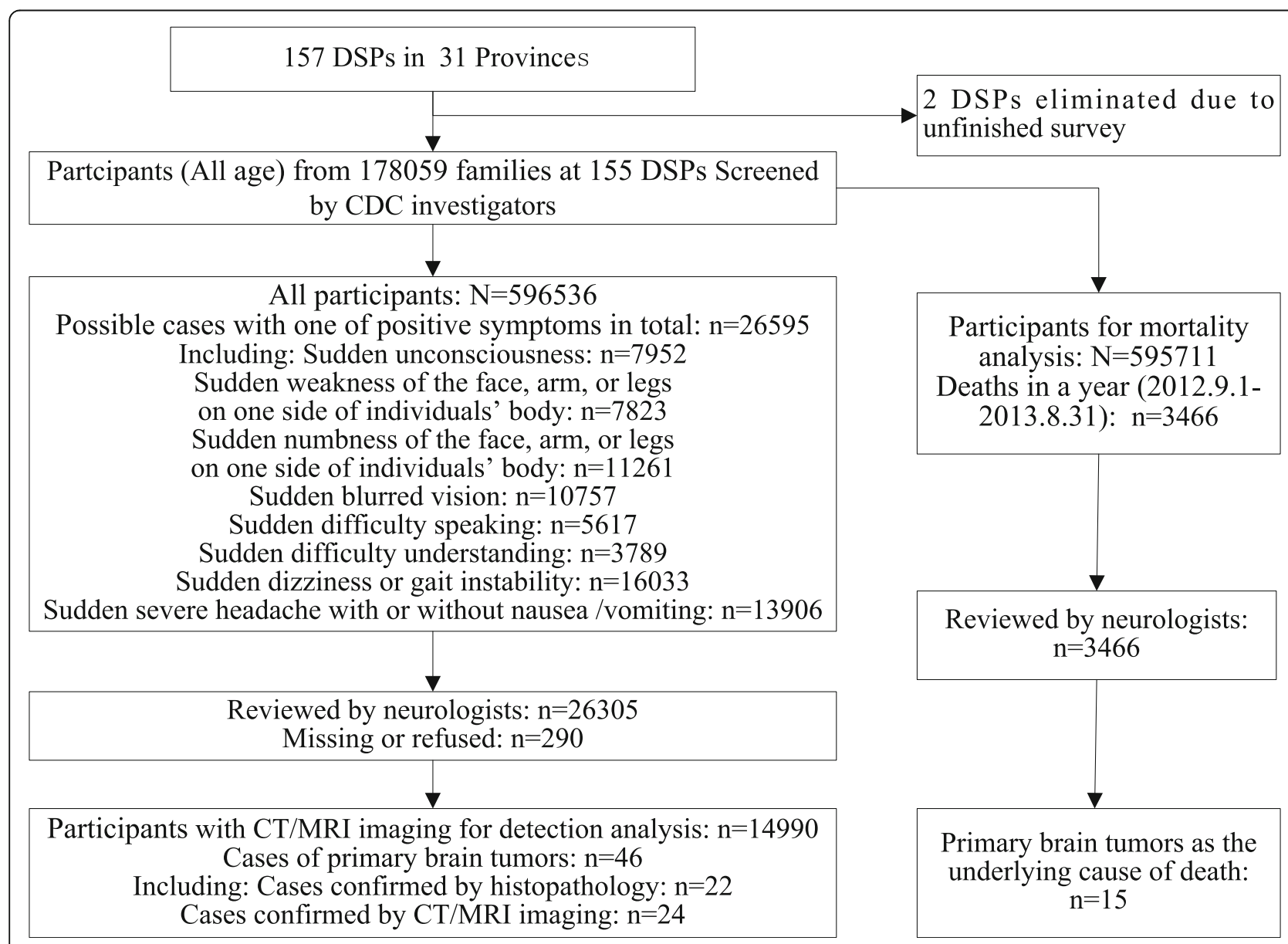

Fig. 2 Flowchart of primary brain tumour case ascertainment. Note: DSP, disease surveillance points; CDC, Center for Disease Control and Prevention 
were as follows: (1) typical history and (/or) symptoms of intracranial tumour; (2) CT/MRI confirmation; (3) diagnosis by a neurosurgeon (based on clinical and radiological examinations) and (/or) surgical and pathological confirmation (with diagnostic proof); (4) neurologist consultation for diagnosis confirmation; and (5) the exclusion of brain metastasis. All the tumours diagnosed in this study were confirmed by hospital examination or operation $[10,11]$. All PBT cases resulting in death were identified based on previous medical histories and death certificates according to the International Classification of Diseases, Tenth Revision, Clinical Modification (ICD-10-CM).

\section{Statistical analysis}

Statistical analyses were conducted with weighted data to account for the complex sampling design. Weighted coefficients were calculated by considering the sampling weights, nonresponse weights, and poststratification weights to obtain the national estimates. Population data from the 2010 Chinese population census were used to calculate poststratification weights adjusted for sex (men, women), age $(0-4,5-9,10-14,15-19,20-24,25-$ 29, 30-34, 35-39, 40-44, 45-49, 50-54, 55-59, 60-64, $65-69,70-74,75-79,80+$ years), residence (urban or rural), and geographic location (eastern, central, or western China) $[6,9]$.

In this retrospective epidemiological survey, mortality due to PBT was defined as the rate of the dead cases with PBT within a year among the survival population prior to midnight on August 31, 2012, from the sampled families. National estimates of mortality and 95\% confidence intervals (CIs) were computed for age and sex groups with final weights.

Similarly, the detection rate of PBTs was defined as the rate of PBT cases confirmed by CT/MRI detection or histopathology among survivors with suspected symptoms (/signs) from the sampled families prior to midnight on August 31, 2013. Crude detection rates and 95\% CIs were estimated with Poisson distribution, because the small counts of brain tumour have the distribution.

Detection rates among people with suspected symptoms (/signs) were calculated and further compared between subgroups in the multivariate analysis. Factors influencing the detection rates of primary brain tumour in participants with suspected symptoms (/signs) were determined after adjustment for different explanatory factors in a binary logistic regression model. The explanatory risk factors included age group $(0-14,15-24$, 25-34, 35-44, 45-54, 55-64, 65-74, $\geq 75$ years); sex (men/women); ethnicity (Han ethnicity/other ethnicity); education (primary school/middle school/college and higher/missing); marriage status (married/single/ widowed/other/missing); occupation (students/worker/ farmer/employee/entrepreneur/retiree or homemaker/ other/missing); place of residence (urban/rural); geographic location (eastern/central/western China); disturbance of consciousness (yes/no); limb paralysis or weakness (yes/no); facial paralysis (yes/no); gait instability (yes/no); speech disorders (yes/no); paraesthesia (yes/ no); visual anomalies (yes/no); dizziness/vertigo (yes/no); headache (yes/no); and nausea/vomiting (yes/no).

All of the statistical calculations were performed with SPSS 15.0 software (SPSS Inc., Chicago, IL, USA). $P<0.05$ was considered statistically significant.

\section{Results}

Characteristics of the participants and patients with PBTs The characteristics of the study sample from the national epidemiological survey of PBTs in China 2013 are shown in Table 1 . Among the 595,711 people included in the mortality analysis, 15 of 3466 deaths occurring between September 1, 2012, and August 31, 2013, were due to PBTs (see Fig. 2 and Table 2). Among the 14,990 people evaluated in the detection rate analysis, 46 survivors with $\mathrm{PBT}$ confirmed by CT/MRI or histopathology were identified on August 31, 2013 (see Fig. 2 and Table 3). There were 2 glioma, 7 pituitary adenoma, 7 meningioma, 3 acoustic neuroma, 1 craniopharyngioma, 1 cerebellar haemangioblastoma, 1 primary central nervous system lymphoma (PCNSL), and 24 undetermined intracranial tumour cases among the 46 cases; $6.5 \%$ experienced conscious disturbance, $28.3 \%$ experienced limb paralysis or weakness, $4.3 \%$ experienced facial paralysis, $30.4 \%$ had an unsteady gait, $13.0 \%$ had speech disorders, $17.4 \%$ experienced paraesthesia, $26.1 \%$ had visual anomalies, $37.0 \%$ had dizziness/vertigo, $47.8 \%$ had headache, and $15.2 \%$ had nausea/vomiting.

\section{Nationwide mortality due to PBTs in China}

In China, the weighted mortality due to PBT was 1.6 (95\% CI $0.8-3.3)$ per 100,000 population, 1.8 (95\% CI $0.7-4.6)$ per 100,000 population in men, and 1.5 (95\% CI $0.5-4.5)$ per 100,000 population in women (see Table 2 ); 1.2 (95\% CI $0.4-3.6$ ) per 100,000 population in urban residents and 2.1 (95\% CI $0.9-5.4$ ) per 100,000 population in rural residents; and 0.5 (95\% CI $0.1-2.2)$ per 100 , 000 among eastern Chinese, 2.4 (95\% CI 1.0-6.0) per 100,000 population in central Chinese, and 2.4 (95\% CI $0.6-9.0)$ per 100,000 population in western Chinese. According to the above-estimated mortality rates, there were 21,215 (95\% CI 10,427-43,165) deaths annually from PBTs in the population, with 11,879 (95\% CI 4641-30,405) deaths in men and 9337 (95\% CI 305928,497) deaths in women in China (see Table 2). 
Table 1 Characteristics of the study sample from the national epidemiological survey of primary brain tumours in China, 2013

\begin{tabular}{|c|c|c|c|c|c|}
\hline \multirow[b]{2}{*}{ Characteristic } & \multicolumn{3}{|c|}{ Sample for mortality } & \multicolumn{2}{|c|}{ Sample for detection rate } \\
\hline & No. & $\%$ & Weighted $^{\mathrm{a}} \%$ & No. & $\%$ \\
\hline \multicolumn{6}{|l|}{ Age group } \\
\hline $0 \sim$ & 85,462 & $14.3 \%$ & $17.4 \%$ & 28 & $0.2 \%$ \\
\hline $15 \sim$ & 81,378 & $13.7 \%$ & $17.3 \%$ & 34 & $0.2 \%$ \\
\hline $25 \sim$ & 89,597 & $15.0 \%$ & $15.1 \%$ & 143 & $1.0 \%$ \\
\hline $35 \sim$ & 102,999 & $17.3 \%$ & $18.5 \%$ & 560 & $3.7 \%$ \\
\hline $45 \sim$ & 90,667 & $15.2 \%$ & $13.4 \%$ & 1917 & $12.8 \%$ \\
\hline $55 \sim$ & 78,075 & $13.1 \%$ & $10.2 \%$ & 4767 & $31.8 \%$ \\
\hline $65 \sim$ & 43,245 & $7.3 \%$ & $5.3 \%$ & 4590 & $30.6 \%$ \\
\hline $75 \sim$ & 24,288 & $4.1 \%$ & $2.9 \%$ & 2951 & $19.7 \%$ \\
\hline \multicolumn{6}{|l|}{ Sex } \\
\hline Men & 299,725 & $50.3 \%$ & $51.1 \%$ & 7296 & $48.7 \%$ \\
\hline Women & 295,986 & $49.7 \%$ & $48.9 \%$ & 7694 & $51.3 \%$ \\
\hline \multicolumn{6}{|l|}{ Ethnicity } \\
\hline Han & 518,151 & $87.0 \%$ & $91.4 \%$ & 13,756 & $91.8 \%$ \\
\hline Other & 77,560 & $13.0 \%$ & $8.6 \%$ & 1234 & $8.2 \%$ \\
\hline \multicolumn{6}{|l|}{ Education, $n(\%)$} \\
\hline Primary school & 245,192 & $41.2 \%$ & $38.9 \%$ & 9176 & $61.2 \%$ \\
\hline Middle school & 294,193 & $49.4 \%$ & $49.2 \%$ & 5297 & $35.3 \%$ \\
\hline College and higher & 51,721 & $8.7 \%$ & $11.3 \%$ & 504 & $3.4 \%$ \\
\hline Missing & 4605 & $0.8 \%$ & $0.5 \%$ & 13 & $0.1 \%$ \\
\hline \multicolumn{6}{|l|}{ Marital status, n (\%) } \\
\hline Married & 391,124 & $65.7 \%$ & $61.2 \%$ & 12,059 & $80.4 \%$ \\
\hline Single & 115,438 & $19.4 \%$ & $23.8 \%$ & 238 & $1.6 \%$ \\
\hline Widowed & 32,731 & $5.5 \%$ & $4.2 \%$ & 2640 & $17.6 \%$ \\
\hline other & 51,402 & $8.6 \%$ & $10.2 \%$ & 33 & $0.3 \%$ \\
\hline Missing & 5016 & $0.8 \%$ & $0.6 \%$ & 20 & $0.1 \%$ \\
\hline \multicolumn{6}{|l|}{ Occupation, $n(\%)$} \\
\hline Students & 105,510 & $17.7 \%$ & $22.4 \%$ & 42 & $0.3 \%$ \\
\hline Worker & 45,004 & $7.6 \%$ & $8.8 \%$ & 620 & $4.1 \%$ \\
\hline Farmer & 270,916 & $45.5 \%$ & $38.8 \%$ & 8343 & $55.7 \%$ \\
\hline Employee & 46,674 & $7.8 \%$ & $9.9 \%$ & 350 & $2.3 \%$ \\
\hline Entrepreneur & 52,516 & $8.8 \%$ & $10.2 \%$ & 393 & $2.6 \%$ \\
\hline Retiree or homemaker & 66,145 & $11.1 \%$ & $8.7 \%$ & 5154 & $34.4 \%$ \\
\hline other & 4356 & $0.7 \%$ & $0.7 \%$ & 76 & $0.5 \%$ \\
\hline Missing & 4590 & $0.8 \%$ & $0.5 \%$ & 12 & $0.1 \%$ \\
\hline \multicolumn{6}{|l|}{ Place of residence } \\
\hline Urban & 282,169 & $47.4 \%$ & $52.8 \%$ & 7628 & $50.9 \%$ \\
\hline Rural & 313,542 & $52.6 \%$ & $47.2 \%$ & 7362 & $49.1 \%$ \\
\hline \multicolumn{6}{|l|}{ Geographic location } \\
\hline Eastern China & 201,196 & $33.8 \%$ & $40.7 \%$ & 4950 & $33.0 \%$ \\
\hline Central China & 239,288 & $40.2 \%$ & $32.0 \%$ & 7073 & $47.2 \%$ \\
\hline Western China & 155,227 & $26.1 \%$ & $27.3 \%$ & 2967 & $19.8 \%$ \\
\hline
\end{tabular}


Table 2 Mortality due to primary brain tumours in China, $2013(1 / 100,000)$

\begin{tabular}{|c|c|c|c|c|c|c|c|c|c|c|}
\hline \multirow[b]{2}{*}{ Age group } & \multicolumn{4}{|l|}{ Men } & \multicolumn{4}{|l|}{ Women } & \multicolumn{2}{|l|}{ Total } \\
\hline & Population & Cases & Mortality* & $95 \% \mathrm{Cl}^{*}$ & Population & Cases & Mortality* & $95 \% \mathrm{Cl}^{*}$ & Mortality* & $95 \% \mathrm{Cl}^{*}$ \\
\hline $0 \sim$ & 45,548 & 0 & -- & -- & 39,914 & 0 & -- & -- & -- & -- \\
\hline $15 \sim$ & 41,209 & 0 & -- & -- & 40,169 & 1 & 0.5 & $0.06-3.3$ & 0.2 & $0.03-1.6$ \\
\hline $25 \sim$ & 44,351 & 0 & -- & -- & 45,246 & 0 & -- & -- & -- & -- \\
\hline $35 \sim$ & 52,561 & 0 & -- & -- & 50,438 & 0 & -- & -- & -- & -- \\
\hline $45 \sim$ & 45,289 & 0 & -- & -- & 45,378 & 1 & 1.4 & $0.2-10.4$ & 0.7 & $0.1-5.1$ \\
\hline $55 \sim$ & 38,189 & 1 & 0.3 & $0.04-2.2$ & 39,886 & 2 & 7.5 & $1.2-46.7$ & 3.9 & $0.7-22.5$ \\
\hline $65 \sim$ & 21,283 & 4 & 26.6 & $8.4-83.5$ & 21,962 & 2 & 5.9 & $1.5-23.9$ & 16.3 & $6.2-42.9$ \\
\hline 75 & 11,295 & 2 & 15.1 & $3.1-73.8$ & 12,993 & 2 & 2.8 & $0.4-18.0$ & 8.2 & $2.2-31.4$ \\
\hline Total & 299,725 & 7 & 1.8 & $0.7-4.6$ & 295,986 & 8 & 1.5 & $0.5-4.5$ & 1.6 & $0.8-3.3$ \\
\hline Subtotal ( $\geq 15)$ & 254,177 & 7 & 2.2 & $0.9-5.6$ & 256,072 & 8 & 1.8 & $0.6-5.3$ & 2.0 & $1.0-4.0$ \\
\hline Death No. & -- & -- & $11,878.8$ & $4640.8-30,405.4$ & -- & -- & 9336.5 & $3058.9-28,496.9$ & $21,215.3$ & $10,427.2-43,164.6$ \\
\hline
\end{tabular}

*Annual mortality between 1 Sept 2012 and 31 Aug 2013; mortalities and 95\% Cls were estimated with individual final weights

\section{Detection rate of PBTs among people with suspected} symptoms (/signs) and influencing factors

Among the 14,990 people with suspected symptoms (/signs), the PBT detection rate was 306.9 (95\% CI 224.7-409.3) per 100,000 population, 233.0 (95\% CI $135.7-373.1)$ per 100,000 population in men, and 376.9 (95\% CI 252.4-541.3) per 100,000 population in women (see Table 3); 262.2 (95\% CI 160.2-404.9) per 100,000 population in urban residents and 353.2 (95\% CI 230.7$517.5)$ per 100,000 population in rural residents; and 222.2 (95\% CI $110.9-397.6)$ per 100,000 population in eastern Chinese, 367.6 (95\% CI 240.1-538.6) per 100,000 population in central Chinese, and 303.3 (95\% CI 138.7575.8 ) per 100,000 population in western Chinese.

The factors influencing detection rates included age, gait disturbance, visual anomalies, dizziness/vertigo, and headache. The detection rate was higher in people aged $35-44$ years than in people aged $\geq 75$ years (OR 5.52;
95\% CI 1.37-22.16; $P=0.016)$, in people with an unsteady gait than in people without an unsteady gait (2.46; $1.09-5.51 ; P=0.029)$, in people with visual anomalies than in people without visual anomalies $(3.84 ; 1.88-$ 7.85; $P<0.001$ ), and in people with headache than in people without headache $(2.06 ; 1.10-3.86 ; P=0.023)$. However, the detection rate was lower in people with dizziness/vertigo than in people without dizziness/vertigo (0.45; 0.23-0.87; $P=0.017$ ) (Table 4).

\section{Discussion}

\section{Mortality due to PBT}

In this survey, the weighted mortality due to PBT was $1.6 / 100,000$ population, $1.8 / 100,000$ population in men, and $1.5 / 100,000$ population in women, excluding tumours originating from spinal cord and brain metastases from other systems outside the central nervous system. The corresponding mortalities were lower than

Table 3 Detection rate of primary brain tumours in participants with suspected symptoms (/signs) $(1 / 100,000)$

\begin{tabular}{|c|c|c|c|c|c|c|c|c|c|c|}
\hline \multirow[b]{2}{*}{$\begin{array}{l}\text { Age } \\
\text { group }\end{array}$} & \multicolumn{4}{|l|}{ Men } & \multicolumn{4}{|l|}{ Women } & \multicolumn{2}{|l|}{ Total } \\
\hline & Population & Cases & $\begin{array}{l}\text { Detection } \\
\text { rate* }^{*}\end{array}$ & $95 \% \mathrm{Cl}^{*}$ & Population & Cases & $\begin{array}{l}\text { Detection } \\
\text { rate* }^{*}\end{array}$ & $95 \% \mathrm{Cl}^{*}$ & $\begin{array}{l}\text { Detection } \\
\text { rate }^{*}\end{array}$ & $95 \% \mathrm{Cl}^{*}$ \\
\hline $0 \sim$ & 19 & 0 & -- & -- & 9 & 0 & -- & -- & -- & -- \\
\hline $15 \sim$ & 20 & 0 & -- & -- & 14 & 2 & $14,285.7$ & $1730.1-51,604.9$ & 5882.4 & $712.4-21,249.1$ \\
\hline $25 \sim$ & 66 & 0 & -- & -- & 77 & 0 & -- & -- & -- & -- \\
\hline $35 \sim$ & 244 & 1 & 409.8 & $10.4-2283.5$ & 316 & 6 & 1898.7 & $696.8-4132.7$ & 1250.0 & $502.6-2575.5$ \\
\hline $45 \sim$ & 895 & 3 & 335.2 & $69.1-979.6$ & 1022 & 6 & 587.1 & 215.4-1277.8 & 469.5 & $214.7-891.2$ \\
\hline $55 \sim$ & 2270 & 3 & 132.2 & $27.3-386.2$ & 2497 & 6 & 240.3 & $88.2-523.0$ & 188.8 & $86.3-358.4$ \\
\hline $65 \sim$ & 2234 & 7 & 313.3 & $126.0-645.6$ & 2356 & 8 & 339.6 & $146.6-669.1$ & 326.8 & $182.9-539.0$ \\
\hline $75 \sim$ & 1548 & 3 & 193.8 & $40.0-566.4$ & 1403 & 1 & 71.3 & $1.8-397.1$ & 135.5 & $36.9-347.1$ \\
\hline Total & 7296 & 17 & 233.0 & $135.7-373.1$ & 7694 & 29 & 376.9 & $252.4-541.3$ & 306.9 & $224.7-409.3$ \\
\hline
\end{tabular}

*Detection rates and $95 \% \mathrm{Cls}$ were estimated based on the Poisson distribution 
Table 4 Factors influencing detection rates in participants with suspected symptoms (/signs) of primary brain tumour

\begin{tabular}{|c|c|c|c|c|c|c|}
\hline Factors & Participants & PBT No. & $\%$ & Adjusted $^{\mathrm{a}}$ OR & $95 \% \mathrm{Cl}$ & $P$ value \\
\hline \multicolumn{7}{|l|}{ Age group, $n(\%)$} \\
\hline $0 \sim$ & 28 & 0 & -- & -- & -- & 0.998 \\
\hline $15 \sim$ & 34 & 2 & $5.9 \%$ & 13.42 & 0.89-202.85 & 0.061 \\
\hline $25 \sim$ & 143 & 0 & -- & -- & -- & 0.996 \\
\hline $35 \sim$ & 560 & 7 & $1.3 \%$ & 5.52 & $1.37-22.16$ & 0.016 \\
\hline $45 \sim$ & 1917 & 9 & $0.5 \%$ & 2.32 & $0.64-8.48$ & 0.203 \\
\hline $55 \sim$ & 4767 & 9 & $0.2 \%$ & 0.95 & $0.27-3.29$ & 0.933 \\
\hline $65 \sim$ & 4590 & 15 & $0.3 \%$ & 1.78 & $0.57-5.61$ & 0.322 \\
\hline $75 \sim$ & 2951 & 4 & $0.1 \%$ & Reference & Reference & \\
\hline \multicolumn{7}{|l|}{ Sex, $n(\%)$} \\
\hline Men & 7296 & 17 & $0.2 \%$ & 0.65 & $0.34-1.23$ & 0.186 \\
\hline Women & 7694 & 29 & $0.4 \%$ & Reference & Reference & \\
\hline \multicolumn{7}{|l|}{ Ethnicity, n (\%) } \\
\hline Han & 13,756 & 39 & $0.3 \%$ & Reference & Reference & \\
\hline Other & 1234 & 7 & $0.6 \%$ & 1.02 & $0.35-2.95$ & 0.966 \\
\hline \multicolumn{7}{|l|}{ Education, $n(\%)$} \\
\hline Primary school & 9176 & 21 & $0.2 \%$ & Reference & Reference & \\
\hline Middle school & 5297 & 22 & $0.4 \%$ & 1.49 & $0.75-2.94$ & 0.253 \\
\hline College and higher & 504 & 0 & -- & -- & -- & 0.993 \\
\hline Missing & 13 & 3 & $23.1 \%$ & 30.07 & $0.09-9575.23$ & 0.247 \\
\hline \multicolumn{7}{|l|}{ Marital status, n (\%) } \\
\hline Married & 12,059 & 36 & $0.3 \%$ & Reference & Reference & \\
\hline Single & 238 & 3 & $1.3 \%$ & 2.96 & $0.51-17.40$ & 0.229 \\
\hline Widowed & 2640 & 4 & $0.2 \%$ & 0.60 & $0.20-1.78$ & 0.361 \\
\hline Other & 33 & 0 & -- & -- & -- & 0.998 \\
\hline Missing & 20 & 3 & $15.0 \%$ & 2.03 & $0.01-593.19$ & 0.808 \\
\hline \multicolumn{7}{|l|}{ Occupation, n (\%) } \\
\hline Students & 42 & 1 & $2.4 \%$ & 0.99 & $0.04-22.32$ & 0.993 \\
\hline Worker & 620 & 1 & $0.2 \%$ & 0.44 & $0.06-3.47$ & 0.436 \\
\hline Farmer & 8343 & 25 & $0.3 \%$ & Reference & Reference & \\
\hline Employee & 350 & 1 & $0.3 \%$ & 1.05 & $0.13-8.44$ & 0.960 \\
\hline Entrepreneur & 393 & 3 & $0.8 \%$ & 1.45 & $0.38-5.45$ & 0.585 \\
\hline Retiree or homemaker & 5154 & 12 & $0.2 \%$ & 1.01 & $0.44-2.36$ & 0.974 \\
\hline Other & 76 & 0 & -- & -- & -- & 0.997 \\
\hline Missing & 12 & 3 & $25.0 \%$ & 5.90 & $0.02-1868.59$ & 0.546 \\
\hline \multicolumn{7}{|l|}{ Place of residence, $n$ (\%) } \\
\hline Urban & 7628 & 20 & $0.3 \%$ & 0.72 & $0.35-1.46$ & 0.359 \\
\hline Rural & 7362 & 26 & $0.4 \%$ & Reference & Reference & \\
\hline \multicolumn{7}{|l|}{ Geographic location, n (\%) } \\
\hline Eastern China & 4950 & 11 & $0.2 \%$ & 0.97 & $0.38-2.48$ & 0.946 \\
\hline Central China & 7073 & 26 & $0.4 \%$ & 1.93 & $0.85-4.40$ & 0.119 \\
\hline Western China & 2967 & 9 & $0.3 \%$ & Reference & Reference & \\
\hline
\end{tabular}

Symptoms (/signs), $n$ (\%)

Conscious disturbance 
Table 4 Factors influencing detection rates in participants with suspected symptoms (/signs) of primary brain tumour (Continued)

\begin{tabular}{|c|c|c|c|c|c|c|}
\hline Factors & Participants & PBT No. & $\%$ & Adjusted $^{\mathrm{a}}$ OR & $95 \% \mathrm{Cl}$ & $P$ value \\
\hline Yes & 1881 & 3 & $0.2 \%$ & 0.42 & $0.12-1.44$ & 0.167 \\
\hline No & 13,109 & 43 & $0.3 \%$ & Reference & Reference & \\
\hline \multicolumn{7}{|c|}{ Limb paralysis or weakness } \\
\hline Yes & 5842 & 13 & $0.2 \%$ & 0.74 & $0.32-1.72$ & 0.480 \\
\hline No & 9148 & 33 & $0.4 \%$ & Reference & Reference & \\
\hline \multicolumn{7}{|c|}{ Facial paralysis } \\
\hline Yes & 2654 & 2 & $0.1 \%$ & 0.26 & $0.06-1.18$ & 0.080 \\
\hline No & 12,336 & 44 & $0.4 \%$ & Reference & Reference & \\
\hline \multicolumn{7}{|c|}{ Unsteady gait } \\
\hline Yes & 4180 & 14 & $0.3 \%$ & 2.46 & $1.09-5.51$ & 0.029 \\
\hline No & 10,810 & 32 & $0.3 \%$ & Reference & Reference & \\
\hline \multicolumn{7}{|c|}{ Speech disorders } \\
\hline Yes & 3525 & 6 & $0.2 \%$ & 0.71 & $0.27-1.87$ & 0.491 \\
\hline No & 11,465 & 40 & $0.3 \%$ & Reference & Reference & \\
\hline \multicolumn{7}{|c|}{ Paraesthesia } \\
\hline Yes & 3594 & 8 & $0.2 \%$ & 0.72 & $0.32-1.64$ & 0.437 \\
\hline No & 11,396 & 38 & $0.3 \%$ & Reference & Reference & \\
\hline \multicolumn{7}{|c|}{ Visual anomalies } \\
\hline Yes & 1777 & 12 & $0.7 \%$ & 3.84 & $1.88-7.85$ & $<0.001$ \\
\hline No & 13,213 & 34 & $0.3 \%$ & Reference & Reference & \\
\hline \multicolumn{7}{|c|}{ Dizziness/vertigo } \\
\hline Yes & 7521 & 17 & $0.2 \%$ & 0.45 & $0.23-0.87$ & 0.017 \\
\hline No & 7469 & 29 & $0.4 \%$ & Reference & Reference & \\
\hline \multicolumn{7}{|c|}{ Headache } \\
\hline Yes & 4503 & 22 & $0.5 \%$ & 2.06 & $1.10-3.86$ & 0.023 \\
\hline No & 10,487 & 24 & $0.2 \%$ & Reference & Reference & \\
\hline \multicolumn{7}{|c|}{ Nausea/vomiting } \\
\hline Yes & 2766 & 7 & $0.3 \%$ & 0.66 & $0.27-1.59$ & 0.351 \\
\hline No & 12,224 & 39 & $0.3 \%$ & Reference & Reference & \\
\hline
\end{tabular}

${ }^{a}$ All other variables in the table were adjusted for each interesting variable in a multivariate logistics regression model

$3.96 / 100,000$ population $(4.30 / 100,000$ population in males and 3.60/100,000 population in females) for brain and CNS tumours, according to the National Central Cancer Registry of China [12], and lower than 2.8 per 100,000 population in males and 2.0 per 100,000 population in females according to annual, global, agestandardized mortality due to primary malignant brain tumours [13]. We speculate that the reason for the difference is most likely attributed to different study designs and diagnostic criteria, although the real cause for the difference is unknown.

Generally, mortality due to PBT is higher in developed regions than in developing regions [13]. However, mortality due to PBT in urban residents was lower than that in rural residents in this survey. Mortality due to PBT in eastern Chinese individuals in developed areas was also lower than those in central and western Chinese individuals in intermediately and underdeveloped areas. Mortality due to intracranial tumours in 21 rural areas was $4.1 / 100,000$ [11], which was higher than $2 / 100,000$ in six cities [10] during the same period. Data from the $\mathrm{Na}$ tional Central Cancer Registry of China were similar; the age-standardized mortality rate in rural areas was 3.33/ 100,000 , which was higher than $2.77 / 100,000$ in urban areas [12]. The true reasons for the contrasting results, as well as differences in detection methods and bias due to the sampling survey method, need to be further explored. Furthermore, mortality due to PBT in China has not increased over the past 30 years according to the analysis of existing studies. 


\section{Implication of an improved detection rate based on PBT symptom screening}

Despite the relatively low prevalence of PBTs in the population, the detection rate of PBTs could be greatly improved by PBT symptom screening (for an unsteady gait, visual anomalies, headache, etc.) according to the data from the survey. Interestingly, patients with dizziness/vertigo were less likely to have brain tumours than those without dizziness/vertigo. This indicates that most brain tumours originating from regions other than the cerebellum or posterior circulation territories did not induce symptoms of dizziness/vertigo. After reviewing the relevant literature, we could not find any information to perform a comparative analysis. The detection rate of brain tumours in the group aged 35-44 years was higher than that in the group aged 75 + years; this may be due to different responses to brain tumour symptoms, leading to incidental discovery. Table 5 lists the study designs and findings of previous PBT prevalence surveys in China and other regions worldwide. In China, three studies have estimated the prevalence of brain tumours; the prevalence rates were 32 (20.91-43.09)/100,000 population in six cities in 1985 [10], 6.9 (1.75-12.05)/ 100,000 population in 21 rural areas in 1989 [11], and 24.56 (14.85-34.27)/100,000 population in five cities in 2011 [14]. Further, the prevalence rates from the three previous studies were obviously lower than $130.8 / 100$, $000,209.0 / 100,000$, and $221.8 / 100,000$ population as reported in the USA [2, 3]; 68/100,000 population in males and 93/100,000 population in females in Sweden [15]; 94/100,000 population for pituitary adenoma in Belgium [16]; and 77.6/100,000 population for pituitary adenoma in England [17]. The results were similar to the 5-year partial prevalence of brain and other CNS tumours at $13.8 / 100,000$ population in males and $15.9 / 100,000$ population in females in France [18], and 26.3/100,000 population for CNS glial tumour and 4.7/100,000 population for CNS nonglial and pineal gland tumours in Europe [4]. We note that these are marked differences in methods and results across different studies on the prevalence of PBTs. Both higher detection and survival rates in developed countries and regions might partially explain why the prevalence rates of primary brain tumours and pituitary adenomas are so higher than those in China.

It should be noted that the importance of PBT detection based on symptom screening is the potential feasibility of investigating the prevalence of PBTs in populations in the future using a two-step method including symptom screening and neurologist review. Moreover, the same method of PBT case ascertainment in the population allows for comparisons of PBT prevalence rates among different populations.

\section{Sex difference in the epidemiology of PBTs}

In both sexes, the incidence of and mortality due to primary benign and malignant brain tumours differs, although no sex differences in mortality and detection were found in this survey. The incidence of and mortality due to malignant brain tumours are generally higher in males than in females. The annual, global, agestandardized incidence of primary malignant brain tumours is $3.7 / 100,000$ population in men and $2.6 / 100,000$ population in women $[13,14]$. The annual, global, agestandardized mortality due to primary malignant brain tumours is $2.8 / 100,000$ population in men and 2.0/100, 000 population in women [13]. Malignant gliomas are more common in males than in females, with a male-tofemale ratio ranging from $1.5: 1$ to $2.2: 1$, whereas benign meningiomas are more common in females than in males, with a male-to-female ratio ranging from $0.5: 1$ to 0.9:1 [1, 19]. Gliomas affect approximately $40 \%$ more males than females, and meningiomas affect approximately $80 \%$ more females than males [20]. A higher incidence of primary glioblastoma (GBM) has been reported in men than in women; however, this is not true for secondary GBM [21]. As mentioned above, the sexual heterogeneity of different types of PBTs may be observed across different populations.

Previous studies have found that men have a higher prevalence of primary malignant brain tumours than women [2, 11]. In contrast, most previous studies confirmed that the prevalence of PBTs in women was higher than that in men $[3,14,15,18]$. The exclusion of benign brain tumours in early studies may explain why the prevalence of brain tumours in males is relatively higher than that in females. To some extent, this explains why the prevalence of PBTs in women is higher than that in men in most studies.

\section{Strengths and limitations}

This survey was a cross-sectional survey, with representativeness of the Chinese population, but it also had many shortcomings. Symptoms such as headache, vomiting, motor and sensory dysfunction, limb weakness, paralysis and numbness, visual impairment, visual field defect, language disorder, and imbalance may help to identify cases; however, a small number of patients with brain tumours may lack specific symptoms. In this study, we did not analyse other symptoms that may be associated with brain tumours, such as convulsions or seizures, olfactory disorders, nervous deafness, mental decline, psychiatric symptoms, endocrine disorders, and developmental abnormalities. Over half of the confirmed brain tumours lacked pathological typing. Forty-two percent of patients with suspected symptoms during preliminary screening who needed further review and diagnosis by a neurologist did not have any CT/MRI data. In 
Table 5 Comparison of designs and findings of previous primary brain tumour prevalence surveys

\begin{tabular}{|c|c|c|c|c|c|c|c|}
\hline $\begin{array}{l}\text { Study, } \\
\text { date, } \\
\text { reference }\end{array}$ & Region & Population & $\begin{array}{l}\text { Prevalence } \\
\text { date }\end{array}$ & Design & Diagnosis & $\begin{array}{l}\text { Prevalence } \\
(1 / 100,000)\end{array}$ & $\begin{array}{l}\text { Subgroup/ } \\
\text { subtype }(1 / 100, \\
000)\end{array}$ \\
\hline $\begin{array}{l}\text { Wang, } \\
1985[10]\end{array}$ & China & $\begin{array}{l}\text { All ages; } 65,067 \\
\text { in urban areas } \\
\text { including six } \\
\text { cities in China }\end{array}$ & Jan 1, 1984 & $\begin{array}{l}\text { Cross-sectional survey, point } \\
\text { prevalence }\end{array}$ & $\begin{array}{l}\text { Clinical } \\
\text { diagnosis; } \\
\text { histology; } \\
\text { imaging }\end{array}$ & $\begin{array}{l}32(20.91- \\
43.09)\end{array}$ & -- \\
\hline $\begin{array}{l}\text { Li, } 1989 \\
{[11]}\end{array}$ & China & $\begin{array}{l}\text { All ages; } 246,812 \\
\text { people in rural } \\
\text { areas of } 21 \\
\text { provinces in } \\
\text { China }\end{array}$ & Jan 1,1985 & $\begin{array}{l}\text { Cross-sectional survey, point } \\
\text { prevalence }\end{array}$ & $\begin{array}{l}\text { Clinical } \\
\text { diagnosis; } \\
\text { histology; } \\
\text { imaging }\end{array}$ & $\begin{array}{l}6.9(1.75- \\
12.05)\end{array}$ & $\begin{array}{l}\text { Men, } 7.3 \text {; women, } \\
6.4\end{array}$ \\
\hline $\begin{array}{l}\text { Jiang, } 2011 \\
{[14]}\end{array}$ & China & $\begin{array}{l}\text { All ages; } 2,589, \\
448 \text { people in } \\
\text { five cities in } \\
\text { China }\end{array}$ & 2006 & $\begin{array}{l}\text { Registry of primary brain tumours, } \\
\text { period prevalence }\end{array}$ & $\begin{array}{l}\text { Clinical } \\
\text { diagnosis; } \\
\text { histology; } \\
\text { imaging }\end{array}$ & $\begin{array}{l}24.56 \\
(14.85- \\
34.27)\end{array}$ & $\begin{array}{l}\text { Men, } 18.84(10.33- \\
\text { 27.35); women, } \\
30.57 \text { (19.73-41.41) }\end{array}$ \\
\hline $\begin{array}{l}\text { Davis, } 2001 \\
\text { [2] }\end{array}$ & USA & $\begin{array}{l}\text { All ages; no data } \\
\text { on population }\end{array}$ & 2000 & $\begin{array}{l}\text { Prevalence rates were estimated using } \\
\text { age-specific incidence rates (1985- } \\
\text { 1994) and survival curves from two } \\
\text { population-based tumour registries } \\
\text { from the Central Brain Tumor Registry } \\
\text { of the United States in a statistical } \\
\text { model. }\end{array}$ & $\begin{array}{l}\text { Behavior } \\
\text { codes; } \\
\text { histology }\end{array}$ & 130.8 & $\begin{array}{l}\text { Benign, 97.5; } \\
\text { malignant, } 29.5 \\
\text { (men, 32.7; } \\
\text { women, 25.9) }\end{array}$ \\
\hline $\begin{array}{l}\text { Porter, } \\
2010[3]\end{array}$ & USA & $\begin{array}{l}\text { All ages; no data } \\
\text { on population }\end{array}$ & 2004 & $\begin{array}{l}\text { An estimate of the prevalence of } \\
\text { disease in the United States based on } \\
\text { incidence data for } 2004 \text { and survival } \\
\text { data for } 1985-2005 \text { obtained by the } \\
\text { Central Brain Tumor Registry of the } \\
\text { United States from selected regions for } \\
\text { the year } 2004 \text {. }\end{array}$ & Histology & 209 & $\begin{array}{l}\text { Men, 158.7; } \\
\text { women, 264.8; } \\
\text { glioma, } 34.3\end{array}$ \\
\hline $\begin{array}{l}\text { Porter, } \\
2010[3]\end{array}$ & USA & $\begin{array}{l}\text { All ages; no data } \\
\text { on population }\end{array}$ & 2010 & $\begin{array}{l}\text { A projected estimate of the prevalence } \\
\text { of disease in the United States based } \\
\text { on incidence data for } 2004 \text { and } \\
\text { survival data for } 1985-2005 \text { obtained } \\
\text { by the Central Brain Tumor Registry of } \\
\text { the United States from selected } \\
\text { regions for the year } 2010 \text {. }\end{array}$ & Histology & 221.8 & -- \\
\hline $\begin{array}{l}\text { Crocetti, } \\
2012[4]\end{array}$ & Europe & $\begin{array}{l}\text { All ages; } 2008 \\
\text { European } \\
\text { population }(497, \\
455,033)\end{array}$ & Jan 1, 2003 & $\begin{array}{l}\text { Point prevalence at the index date } \\
\text { estimated based on incidence and } \\
\text { follow-up data from } 22 \text { population- } \\
\text { based cancer registries; }\end{array}$ & $\begin{array}{l}\text { Cancer } \\
\text { registries } \\
\text { coded } \\
\text { according } \\
\text { to ICD-O-3 }\end{array}$ & -- & $\begin{array}{l}\text { Glial tumour of } \\
\text { CNS, 26.3; non- } \\
\text { glial tumour of } \\
\text { CNS and pineal } \\
\text { gland, } 4.7\end{array}$ \\
\hline $\begin{array}{l}\text { Adami, } \\
1989[15]\end{array}$ & Sweden & $\begin{array}{l}\text { All ages; } 8.3 \\
\text { million } \\
\text { inhabitants } \\
\text { constituting the } \\
\text { Swedish } \\
\text { population }\end{array}$ & $\begin{array}{l}\text { Dec 31, } \\
1984\end{array}$ & $\begin{array}{l}\text { National Swedish Cancer Registry, } \\
\text { point prevalence }\end{array}$ & $\begin{array}{l}\text { Clinical } \\
\text { diagnosis; } \\
\text { histology }\end{array}$ & -- & $\begin{array}{l}\text { Men, 68; women, } \\
93\end{array}$ \\
\hline $\begin{array}{l}\text { Daly, } 2006 \\
\text { [16] }\end{array}$ & Belgium & $\begin{array}{l}\text { All ages; } 71972 \\
\text { inhabitants in } \\
\text { Belgium }\end{array}$ & $\begin{array}{l}\text { Sep 30, } \\
2005\end{array}$ & $\begin{array}{l}\text { Cross-sectional hospital-based clinic re- } \\
\text { view, point prevalence }\end{array}$ & $\begin{array}{l}\text { Clinical } \\
\text { diagnosis; } \\
\text { histology; } \\
\text { hormonal } \\
\text { workup }\end{array}$ & -- & $\begin{array}{l}\text { Pituitary adenoma, } \\
94 \text { (72.2-115.8) }\end{array}$ \\
\hline $\begin{array}{l}\text { Fernandez, } \\
2010[17]\end{array}$ & $\begin{array}{l}\text { Banbury, } \\
\text { Oxfordshire, } \\
\text { England }\end{array}$ & $\begin{array}{l}\text { All ages; } 81149 \\
\text { inhabitants in } \\
\text { Banbury }\end{array}$ & Jul 31, 2006 & $\begin{array}{l}\text { Cross-sectional administrative } \\
\text { database, point prevalence }\end{array}$ & $\begin{array}{l}\text { Clinical } \\
\text { diagnosis; } \\
\text { histology; } \\
\text { hormonal } \\
\text { workup }\end{array}$ & -- & $\begin{array}{l}\text { Pituitary adenoma, } \\
77.6\end{array}$ \\
\hline $\begin{array}{l}\text { Colonna, } \\
2008[18]\end{array}$ & France & $\begin{array}{l}\text { All ages; whole } \\
\text { French } \\
\text { population; no } \\
\text { data on } \\
\text { population }\end{array}$ & 1998-2002 & $\begin{array}{l}\text { Incidence and survival data from } \\
\text { French cancer registries were used to } \\
\text { estimate specific 5-year partial preva- } \\
\text { lence rates }\end{array}$ & $\begin{array}{l}\text { Cancer } \\
\text { registries } \\
\text { coded } \\
\text { according } \\
\text { to ICD-O-3 }\end{array}$ & -- & $\begin{array}{l}\text { Men, 13.8; women, } \\
15.9\end{array}$ \\
\hline
\end{tabular}


addition, symptomatic retrospective bias is inevitable. The incidence of brain tumours in children is generally lower than that in adults, and no brain tumours in children were found in this survey, indicating that the symptom screening method is not suitable for epidemiological investigations of brain tumours in children. Nonetheless, we believe that the findings of this survey accurately reflect the rates in people over 15 years old.

\section{Conclusions}

In summary, this survey accurately represented for mortality due to PBTs in China. It is estimated that 21,215 $(10,427-43,165)$ deaths from primary brain tumour occur annually in China. Although the incidence and prevalence of PBTs were relatively low in the population, the detection rate of PBTs can be greatly improved by symptom screening. These findings could provide a data reference for relevant health administrative departments or professional associations tasked with health care policy making or disease management in patients with brain tumours.

\section{Abbreviations}

PBTs: Primary brain tumours; PPS: Probability proportionate to population size; DSPs: Disease surveillance points; CDC: Center for Disease Control and Prevention; ICD-10-CM: International Classification of Diseases, Tenth Revision, Clinical Modification; CT: Computed tomography; MRI: Magnetic resonance imaging; Cls: Confidence intervals

\section{Acknowledgements}

We thank Drs. Liangyou Wu and Lingzhi Kong from the Ministry of Health, China, and Drs. Xiaofeng Liang, Limin Wang, and Linhong Wang from the Chinese Center for Disease Control and Prevention. We also thank all the 383 neurologists and 1626 CDC staff from 31 provinces who worked very hard to ensure the accuracy of the data, and all the study participants for their participation and contribution.

\section{Role of the funder}

The funding party had no role in the study design, data collection, analysis, interpretation, or the writing of the report. The project investigators were responsible for the decision to submit the report for publication.

\section{Authors' contributions}

BJ and WW were the principal investigators responsible for the survey. All authors contributed to the study design, its implementation and field works, data collection, and analysis. BJ performed the statistical analysis and manuscript writing. All contributors discussed the findings and approved the final version for publication.

\section{Funding}

This study was funded by the Ministry of Science and Technology and the Ministry of Health of the People's Republic of China under grant No. 2011BAI08B01 of the National Key Technology R\&D Program, and the National Natural Science Foundation of China under grant No. 81571130090.

\section{Availability of data and materials}

The manuscript does not refer to any new software, application, or tool. The authors do not wish to share data analysed in this manuscript as no such consent was provided by the investigated participants and no approval of the Bioethics Committee was obtained.

\section{Declarations}

\section{Ethical approval and consent to participate}

This study was approved by the Ethics Committee of the Beijing Tiantan Hospital affiliated with Capital Medical University. Written informed consent was obtained from all participants or their caregivers. This study was performed in accordance with the Declaration of Helsinki.

\section{Consent for publication}

Not applicable.

\section{Competing interests}

The authors declare no competing interests.

\section{Author details}

'Department of Neuroepidemiology, Beijing Neurosurgical Institute, Beijing Tiantan Hospital, Capital Medical University, No. 119, South Fourth Ring Road West, Fengtai District, Beijing 100070, People's Republic of China. ${ }^{2}$ Beijing Municipal Key Laboratory of Clinical Epidemiology, Beijing, People's Republic of China. ${ }^{3}$ National Office for Cerebrovascular Diseases (CVD) Prevention and Control in China, Beijing, People's Republic of China.

Received: 9 December 2020 Accepted: 26 February 2021

Published online: 12 March 2021

\section{References}

1. Jiang B. Epidemiology of intracranial tumors. In: Zhao J, Jiang T, editors. Brain tumor surgery (Version 2). Beijing: People's Medical Publishing House; 2020. p. 14-35. (in Chinese).

2. Davis FG, Kupelian V, Freels S, McCarthy B, Surawicz T. Prevalence estimates for primary brain tumors in the United States by behavior and major histology groups. Neuro Oncol. 2001;3(3):152-8. https://doi.org/10.1093/ neuonc/3.3.152.

3. Porter KR, McCarthy BJ, Freels S, Kim Y, Davis FG. Prevalence estimates for primary brain tumors in the United States by age, gender, behavior, and histology. Neuro Oncol. 2010;12(6):520-7. https://doi.org/10.1093/neuonc/ nop066.

4. Crocetti E, Trama A, Stiller C, Caldarella A, Soffietti R, Jaal J, Weber DC, Ricardi U, Slowinski J. Brandes A; RARECARE working group. Epidemiology of glial and non-glial brain tumours in Europe. Eur J Cancer. 2012;48(10): 1532-42. https://doi.org/10.1016/j.ejca.2011.12.013.

5. Wang W, Jiang B, Sun H, Ru X, Sun D, Wang L, Wang L, Jiang Y, Li Y, Wang Y, Chen Z, Wu S, Zhang Y, Wang D, Wang Y, Feigin VL. Prevalence, incidence and mortality of stroke in China: results from a nationwide population-based survey of 480,687 adults. Circulation. 2017;135(8):759-71. https://doi.org/10.1161/CIRCULATIONAHA.116.025250.

6. Jiang B, Sun H, Ru X, Sun D, Chen Z, Liu H, Li Y, Zhang M, Wang L, Wang L, Wu S, Wang W. Prevalence, incidence, prognosis, early stroke risk and stroke-related prognostic factors of definite or probable transient ischemic attacks in China, 2013. Front Neurol. 2017;8:309. https://doi.org/10.3389/ fneur.2017.00309 eCollection 2017.

7. Chen Z, Jiang B, Ru X, Sun H, Sun D, Liu X, Li Y, Li D, Guo X, Wang W. Mortality of stroke and its subtypes in China: Results from a nationwide population-based survey. Neuroepidemiology. 2017;48(3-4):95-102. https:// doi.org/10.1159/000477494.

8. Ru X, Wang W, Sun H, Sun D, Fu J, Ge S, Wang L, Wang L, Jiang B. Geographical difference, rural-urban transition and trend in stroke prevalence in China: findings from a national epidemiological survey of stroke in China. Sci Rep. 2019;9(1):17330. https://doi.org/10.1038/s41598-01953848-1.

9. Jiang B, Sun D, Sun H, Ru X, Liu H, Ge S, Wang L, Wang L, Wang W. Annual rates of and factors influencing inpatient and outpatient transient ischaemic attacks in Chinese population: a nationally representative cross-sectional survey. BMJ Open. 2020;10(3):e033786. https://doi.org/10.1136/bmjopen-201 9-033786.

10. Wang ZC, Cheng XM, Li SC, Wang WZ, Wu SP, Wang KJ, Zhou SX, Zhao F, Dai QS, Song JR, Cai Y. Prevalence survey of neurological system diseases in six cities of China. Chin J Neurosurg (Chin). 1985;1(1):2-8.

11. Li BQ, Yang ZM. Epidemiological study of intracranial tumors.Chin. J Neurosurg (Chin). 1989;5(Suppl):48-50. 
12. Chen W, Zheng R, Zuo T, Zeng H, Zhang S, He J. National cancer incidence and mortality in China, 2012. Chin J Cancer Res. 2016;28(1):1-11. https://doi. org/10.3978/j.issn.1000-9604.2016.02.08.

13. Bondy ML, Scheurer ME, Malmer B, Barnholtz-Sloan JS, Davis FG, Il'yasova D, Kruchko C, McCarthy BJ, Rajaraman P, Schwartzbaum JA, Sadetzki S, Schlehofer B, Tihan T, Wiemels JL, Wrensch M, Buffler PA. Brain Tumor Epidemiology Consortium. Brain Tumor Epidemiology: Consensus from the Brain Tumor Epidemiology Consortium. Cancer. 2008;113(7 suppl):1953-68. https://doi.org/10.1002/cncr.23741.

14. Jiang $T$, Tang GF, Lin $Y$, Peng $X X$, Zhang $X$, Zhai XW, Peng $X$, Yang JQ, Huang HE, Wu NF, Chen XJ, Xing HX, Su TY, Wang ZC. Prevalence estimates for primary brain tumors in China: a multi-center cross-sectional study. Chin Med J (Engl). 2011; 124(17): 2578-2583. Doi: 10.3760/cma.j.jssn.0366-6999.201 1.17.003.

15. Adami HO, Gunnarsson T, Sparén P. Eklund G. The prevalence of cancer in Sweden 1984. Acta Oncol. 1989;28(4):463-70. https://doi.org/10.3109/02841 868909092251

16. Daly AF, Rixhon M, Adam C, Dempegioti A, Tichomirowa MA, Beckers A. High prevalence of pituitary adenomas: a cross-sectional study in the province of Liege, Belgium. J Clin Endocrinol Metab. 2006;91(12):4769-75. https://doi.org/10.1210/jc.2006-1668.

17. Fernandez A, Karavitaki N, Wass JAH. Prevalence of pituitary adenomas: a community-based, cross-sectional study in Banbury (Oxfordshire, UK). Clin Endocrinol (Oxf). 2010;72(3):377-82. https://doi.org/10.1111/j.1365-2265.2009. 03667.x.

18. Colonna M, Danzon A, Delafosse P, Mitton N, Bara S, Bouvier AM, Ganry O, Guizard AV, Launoy G, Molinie F, Sauleau EA, Schvartz C, Velten M, Grosclaude P, Tretarre B. Cancer prevalence in France: time trend situation in 2002 and extrapolation to 2012. Eur J Cancer. 2008:44(1):115-22. https://doi.org/10.1016/j.ejca.2007.10.022.

19. Bondy M, Ligon BL. Epidemiology and etiology of intracranial meningiomas: A review. J Neuro Oncol. 1996;29(3):197-205. https://doi.org/10.1007/bf001 65649.

20. Wrensch M, Minn Y, Chew T, Bondy M, Berger MS. Epidemiology of primary brain tumors: Current concepts and review of the literature. Neuro Oncol. 2002;4(4):278-99. https://doi.org/10.1093/neuonc/4.4.278.

21. Thakkar JP, Dolecek TA, Horbinski C, Ostrom QT, Lightner DD, BarnholtzSloan JS, Villano JL. Epidemiologic and molecular prognostic review of glioblastoma. Cancer Epidemiol Biomarkers Prev. 2014;23(10):1985-96. https://doi.org/10.1158/1055-9965.EPI-14-0275.

\section{Publisher's Note}

Springer Nature remains neutral with regard to jurisdictional claims in published maps and institutional affiliations.

Ready to submit your research? Choose BMC and benefit from:

- fast, convenient online submission

- thorough peer review by experienced researchers in your field

- rapid publication on acceptance

- support for research data, including large and complex data types

- gold Open Access which fosters wider collaboration and increased citations

- maximum visibility for your research: over $100 \mathrm{M}$ website views per year

At $\mathrm{BMC}$, research is always in progress.

Learn more biomedcentral.com/submissions 